measuring more than ro feet 6 inches in the skin. He saw the skin of one at Dinagepore, over I 2 feet in length; this was also no doubt stretched. Col. J. Macdonald has killed a tiger of Io feet 4 inches. He says : "I do believe tigers have exceptionally reached 2 feet."

The Hon. R. Drummond, C.S., killed a tiger I I feet 9 inches in length before being skinned.

Col. Shakespeare killed a tiger of I I feet 8 inches.

In regard to the allusion to Buffon's tiger of 15 feet, and Hyder Ally's of I 8 feet, I refer to but to express my distrust of them.

It is needless to adduce further evidence. I repeat that though male tigers over ro feet may be uncommon, they do occasionally (and I said no more) attain the greater size.

June 17

\section{J. FAYrer}

\section{Zoological Geography}

IN the annual address of the President of the Geological Socicty of London, just issued, an extract is given by anticipation from the forthcoming work of Dr. Günther, on the gigantic land-tortoises, wherein that naturalist discusses the question of the geographical connections by which the tortoises of the Mascarine region may have been related to those which are found in the Galapagos Islands.

As neither in this extract nor in the presidential discussion do I find any allusion to the circumstance that, according to the paper of Dr. Litton For'es, in the Fournal of the Geographical Society for 1877 , Didunculus strigirostris, a near congener of the Mascarine Dodo, is living in Upoltr, one of the islands of the Navigator group, I venture to call attention to it. Since this island lies in $\mathrm{I}_{4}^{\circ} \mathrm{S}$. lat., and is distant $130^{\circ}$ of longitude, in a direct line eastwards from the Mauritius, towards the Galapagos, the presence on it of this ground-bird seems to show that the ancient geographical connection from the Mascarene to the Galapagos Islands was eastwards across the Indian and Pacific Oceans, rather than, as Dr. Günther thinks, westwards by way of Africa, the Atlantic, and South America; for by it more than three-fifths of the $210^{\circ}$ of longitude, which in the easterly direction separates the Mascarine region from the Galapagos, and presents a difficulty to Dr. Guinther, are bridged over.

The Navigator group, together with a multitude of other islands in the South Pacific, which extend to within $40^{\circ}$ longitude of the Galapagos, appear to be small remnants of that continent of very remote geological age of which Australia, New Guinea, and New Zealand constitute larger remnants; and perhaps may be allowed to observe that the suggestion made by Dr. Giinther in reference to the extinction of the gigantic tortoises, viz., that they may be supposed to have once spread over the whole of the large area which connects the places of their present occurrence, but to have been unable to survive the arrival of man or the large carnivora, is precisely that which, many years ago, I offered as the explanation of the extinction of the great wing less, or ground-birds, wherever they were unprotected from these enemies by insulation. This formed part of the argument by which in I860 I endeavourecl to show to the Geological Society that most of the land-tracts of the southern hemisplhere were remnants of an ancient continent, which had become insulated at different times during the secondary or mesozoic period.

Martlesham, Suffolk, May 27 SeArles V. Wood, Jun.

\section{Time and Longitude}

In NATURE, vol. vii. p. 68, the Rev. J. Pearson asked, "In what part of the globe and in what meridian does October 20 end and October $2 \mathrm{I}$ begin?"

The question was answered by several correspondents. Still the following may be interesting as a matter of fact in comnection with Mr. Latimer Clark's letter in your issue of May 9.

The date was fixed in many of the Pacific Islands by the early missionaries, who, sailing eastward from Australia, kept the date of the eastern hemisphere after they had crossed the meridian of $180^{\circ}$. This imaginary boundary line cuts through the Fiji Islands, the principal islands of the group being in the eastern hemisphere. It would, of course, be inconvenient to have two dates in one group of islands, especially as the meridian of $180^{\circ}$ passes through the north-east point of Vanua Levu, the island of

I Quarterly Foumal of the Geological Society for 1860 , p. 329 ; Phit. Mag. for March, April, and May, 1862.

Taviuni, and another small island. Such an arrangement might possibly lead to the necessity (if a stickler for strict accuracy should build his house across the line) of a person going from one day to another by passing from one part of the house to another. It would, to say the least, be awkward to sleep during the night of October 20-2I and on arising on the morning of October 21 , by simply walking into the breakfast-room, to cross the boundary-line, and find oneself back into the beginning of October 20.

The Tongan and Samoan Islands are a few degrees east of the meridian of $180^{\circ}$; consequently they ought to be a day behind the neighbouring Fiji group. But hitherto their chief commercial intercourse has been with Australia and New Zealand; and this, for the sake of convenience, has led to the date of the eastern hemisphere being retained up to the present time, although a change has been advocated in Samoa more than once.

In consequence of the present arrangement these little islands have the honour of leading the world in the matter of time, whereas they ought, according to their geographical position, to wind up the rear. There is, however, one drawback to the honour : all our dates, when compared with those of the rest of the world, need to be put back twenty-four hours. This should be remembered in connection with observations of natural phe. nomena. To obtain local time we add 12 hours 33 minutes to G.M.T. instead of subtracting II hours 27 minutes.

S. J. WhitMEe

\title{
New Lunar Crater
}

I was much interested in the account which your last number (vol. xviii. p. 197) contained of the presumably new lunar crater discovered by Dr. Klein in the Mare Vaporum. Is it really necessary to ascribe the formation of such a crater to present volcanic action? It seems to me that this singular phenomenon of the birth of a new crater may be more likely owing to such action having, in long-past ages, left (as in all probability it would leave) extensive caverns beneath the visible surface of our satellite. Such caverns might, in consequence of the gradual changes which the action of the sun's rays, alternating with intense cold, must produce on the lunar rocks, occasionally, give way. A crater-like cavity would then be caused on the moon's surface by this subsidence, such as are not unfrequently seen in mining districts where old workings have fallen in. The fact that the new crater is elliptical, and not round, seems to add to the probability of its having been caused by some such "settling" process. If the crater were produced by active volcanic agency, it would surely be circular, or nearly so. I do not find this mode of quasi-crater formation suggested in Nas. myth's book, nor, so far as I can remember, in any other. Is it not, however, a possible cause of change on the surface of our satellite?

Cardiff, June 22 EDWARD GREENHOW

\section{Opening of Museums on Sundays}

I AM delighted to find from my friend Prof. Dyer's letter tha I was mistalien in the belief that the Maidstone Museum was "the first and only scientific museum that has yet been opened on Sunday in the United Kingdom."

Still the fact that "the Botanical Museum of the Royal Gardens, Kew," is not closed when the Gardens are opened to the public on Sunday, a fact which I had overlooked, althoutgh important enough in itself, is not for a moment to be compared with the deliberate opening of the Maidstone Museum by the town authorities.

Had the Botanical Museum not been attached to the Royal Gardens there can be no doubt that it would still be closed on Sunday, as the British and South Kensington Museums are; the opening of one of these institutions would be a parallel case to that of Maidstone.

I am happy to be able to state that a motion for rescinding the resolution under which the Maidstone Museum was opened on Sunday has been defeated in the Town Council.

May I express a hope that there are many towns which will not long remain behind Maidstone in this matter.

Io, Bolton Row,

Mayfair, W.

W. H. CORFIELD,

Chairman of the Committee of the Sunday Society

P.S.-I have just been reminded that the Natural History Museum in Dublin has been open to the public on Sundays for 